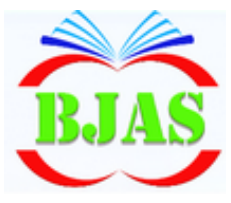

ISSN $1814-5868$
Available online at http://bjas.bajas.edu.iq

https://doi.org/10.37077/25200860.2020.33.1.17

College of Agriculture, University of Basrah

Basrah J. Agric. Sci. 33(1): 221-230, 2020
Basrah Journal of Agricultural Sciences

E-ISSN: 2520-0860

\title{
Effect of Alcoholic Extract of Garden Rocket Eruca sativa Mill. Seed on Some Reproductive Traits and Carcasses Quality of Aged Local Duck Males
}

\author{
Khalid C. K. Al-Salhie \& Ghaidaa A. Makki \\ Department of Animal Production, College of Agriculture, University of Basrah, Basrah, \\ Iraq \\ Corresponding author: Knnz1977@yahoo.com
}

Received 8 April 2020; Accepted 15 June 2020; Available online 29 June 2020

\begin{abstract}
This study aimed to investigate the impacts of Eruca sativa seed extract on some reproductive indicators and carcasses quality for aged local duck males. Forty-five aged local ducks males with the average live-weight of $(2000 \pm 5 \mathrm{~g})$ and two years old were randomly distributed into three treatments (15 for each). After dissolution in corn oil, T2 and T3 were supplemented with 400 and $800 \mathrm{mg}$ alcoholic extract of Eruca sativa seed respectively.T1 has only given corn oil (control). Weekly, a dosage of $2 \mathrm{ml}$ was twice given to the treatments by syringe. The current results showed significant $(\mathrm{P}<0.05)$ increases in the relative weight, length, width and volume of testes in males of second and third treatments compared to the first treatment (control). Besides, the second and third treatments recorded significant $(\mathrm{P}<0.05)$ improvements in the diameter of seminiferous tubules, seminiferous epithelium thickness $(\mu \mathrm{m})$ of testes, the Luteinizing hormone (LH), Follicle-stimulating hormone (FSH) and the level of testosterone hormone compared to the control. Chemical and physical tests of the breast meat showed no significant among all treatments in the ratio of free fatty acids, $\mathrm{pH}$ and water tolerability. Regarding the peroxide number, second treatment recorded the lowest significant $(\mathrm{P}<0.05)$ compared to other treatments. It concluded that alcoholic extract of Eruca sativa seed could enhance reproductive characteristics and significantly improve sex hormones in aged local duck males and effect on the number of peroxide in its breast meat.
\end{abstract}

Keywords: Eruca sativa, Duck, Reproductive Traits,

\section{Introduction}

Duck breeding is common in most of the world's countries. In order to increase the interest in the breeding of duck, it is important to understand the physiological and reproductive characteristics of these animals (Okpe \& Udoumoh, 2016). Most birds reproductive and physiological characteristics are affected by environmental and nutritional variables that influence the growth of gonadal status and function (Davies et al., 2015). Infertility and subsequent complications are regarded as one of the most significant problems for couples. Several factors impact such as sperm production and are attached to infertility survival rate (Mohammadi et al, 2017). Histological study of the testes is very important for detecting the development of spermatogenesis (Ballester et al, 2004). 
Herbal treatments are significantly safer conventional (chemical) medicine. Using herbs can have beneficial impacts on increasing fertilization, production, eliminating problems such as sexual incapacity, hormonal imbalance and low sperm mobility (Amin \& Hamza, 2006; AlSalhie \& Al-Waeli, 2019 ; Sultan et al,2019 ; 2020). Eruca sativa is complete of several protective vitamins that can be used in the therapy of physiological and autoimmune diseases. At the end of the 19th century, it has been used for blood filtering and also for pulmonary diseases (Shahrokhi et al, 2009). The use of $E$. sativa has also been recorded to avoid cell damage and to increase the amount of antioxidant in the body (Chung et al, 1992). This crop has been suggested for use in rheumatism, gout, renal disease, liver, infection, icterus and hypoglycemia (Getahun \& Chung, 1999). Seed and oil of E. sativa had high crude protein, palmitic acid, stearic acid, oleic acid, linoleic acid and erucic acid (Nail et al, 2017). It has strong active components that could be effective in raising health and disease prevention (Helana et al, 2011). because they use traditional cures instead of

The objective of this study is to find out the impacts of E. sativa seed extract on fertilization indicators, sex hormone rates and carcasses meat quality for aged local duck males.

\section{Materials \& Methods}

The present study was conducted in the field of water birds associated with the Agriculture College at the University of Basrah. Fortyfive males from aged local ducks, two years old, with the average live-weight of $2000 \pm 5 \mathrm{~g}$ were randomly divided into three treatments (15 for each). The males were housed in individual cages $(2 \times 2 \times 1 \mathrm{~m})$. The birds were fed the experimental diet (table 1) from the first day to the end of the study (45 days) according to NRC (1994). Ducks were given ad libitum access to food and water. Three treatments have been used in this experiment. The treatments were as following $\mathrm{T} 1$ has only given corn oil (control). After dissolving in corn oil, T2 and T3 were supplemented with 400 and $800 \mathrm{mg}$ of $E$. sativa alcoholic extract respectively. Weekly, a dosage of $2 \mathrm{ml}$ was

Table (1): Compositions and chemical analysis of the experimental diet.

\begin{tabular}{|c|c|}
\hline Ingredients & Diet $(\%)$ \\
\hline Yellow corn & 30 \\
\hline Wheat & 37 \\
\hline Barley & 10 \\
\hline Protein concentrated & 3 \\
\hline Soybean meal & 12.7 \\
\hline Limestone & 7 \\
\hline Iodide salt & 0.3 \\
\hline Total & 100 \\
\hline \multicolumn{2}{|c|}{ Chemical analysis } \\
\hline Metabolized energy $\left(\mathrm{kcal} . \mathrm{kg}^{-1}\right)$ & 2884.7 \\
\hline Protein $(\%)$ & 15.02 \\
\hline Lysine & 0.68 \\
\hline Methionine+ Cysteine & 0.51 \\
\hline Calcium (\%) & 2.65 \\
\hline Phosphorus (\%) & 0.38 \\
\hline Calorie/ protein & 192.05 \\
\hline
\end{tabular}


twice given to the treatments by syringe via ducks mouth. Garden rocket seed obtained from a local market in the city of Basrah, Iraq. The Scientific and common names of plant were followed Garg \& Sharma (2014)

\section{Testes parameters}

Five males were slaughtered from each treatment at the end of the study. Both testes were removed and weighed by a delicate scale. Using a vernier caliper to measure the length and width of testes. The testes volume was calculated by $\left(\mathrm{cm}^{3}\right)$ according to (Vatsalya \& Arora, 2012). A small part of the testis $(5 \mathrm{~g})$ was taken from each treatment and fixed in Bouin's fluid for 24 hours, then dehydrated in ethanol, cleared in xylene and embedded in paraffin. The tissue were cut into $5 \mu \mathrm{m}$ sections with a rotating microtome, stained with haematoxylin and eosin (H \& E). examined with compound microscope, The tubular diameter and thickness of the seminiferous epithelium of the seminiferous tubules were measured using a standardized ocular micrometre by choosing 10 round or almost round tubes (Segatelli et al, 2004).

\section{Hormones measurement}

During slaughter, blood samples were collected from the Jugular vein and centrifuged at 3000 RPM for 10 minutes to obtain serum. The radioimmunoassay were used to measure serum LH and FSH hormones (Peegel et al, 2005). Serum testosterone hormone was tested using an immunoassay kit (DRG Co, Germany).

\section{The number of peroxides}

Parts of breast meat $(5 \mathrm{~g})$ were taken to detection the peroxide number, free fatty acids, $\mathrm{pH}$ and water tolerability. The number of peroxides was determined by AOAC (2016) according to the following equation:
Peroxide value $=\frac{\left(\mathrm{Na}_{2} \mathrm{~S}_{3} \mathrm{O}_{4} \mathrm{ml} \times \mathrm{N} \times 1000\right)}{(\text { Wt.of Sample, gm })}$

\section{The ratio of free fatty acids}

The ratio of free fatty acids (FFA) were estimated based on AOAC (2016) according to the following equation:

Free Fatty Acid $\%=\frac{\text { Titration }(A-B) \times N \times 282 \times 100}{1000 \times \text { Wt of Sample, gm }}$.

$\mathrm{A}=$ Number of $\mathrm{KOH}$ of the sample with the fat or oil sample.

$\mathrm{B}=$ number of $\mathrm{KOH}$ of the sample with the sample

282 = weight of molecular oleic acid.

\section{The pH measurements}

The $\mathrm{pH}$ was estimated by using the $\mathrm{pH}$ meter. The water tolerability was calculated according to the method mentioned by Eady et al, (2014) as the following equation: \% Associated water $=\mathrm{c} \%$ original moisture-free water in the sample.

\section{Statistical Analysis:}

An one - way variance analysis (ANOVA) was applied to analyse data. L.S.D was used to compare among means at level of 0.05 (SPSS, 2016). The experiment carried out with triplicates.

\section{Results \& Discussion}

Right and left testes parameters were showed in tables (2). Statistical analyses showed a significant $(\mathrm{P}<0.05)$ increase in the relative weight, length, width and volume of testes in the second and third treatments compared to control. The highest significant $(\mathrm{P}<0.05)$ difference was seen in third treatment compared to control treatment. Testis size is directly related to the number of Sertoli and sperm cells produced so that the testis size represents the intensity of germ cells in the testis (Manach et al, 1998). This increase in the most testes parameters may be due to the 
potential of the garden rocket extract to stimulate testicular growth and increase the spread, maturation and development of sperm cells (Merz et al, 2000). Several medicinal plants are being used as fertility enhancers (Yakubu et al, 2007). Garden rocket seed oil has been reported to be commonly used by males to enhance their sexual function (Kim et al, 2004). E. sativa seed oil has positively affected fertility and the reproductive system.
Also, several studies have shown that both the aqueous and ethanolic extracts of the rocket plant improved reproductive characteristics (Merza et al, 2000; Hussein, 2013). These findings may be due to high levels of the Luteinizing hormone (LH), Folliclestimulating hormone (FSH) and the testosterone hormone (table 4).These hormones promote the growth and development of testes (Al-Salhie, 2018).

Table (2): Effect of alcoholic extract of $E$. sativa seed on some testes parameters for aged local duck males (Mean \pm SE).

\begin{tabular}{|c|c|c|c|c|}
\hline \multicolumn{2}{|c|}{ Traits } & T1 & $\mathrm{T} 2$ & T3 \\
\hline \multicolumn{2}{|c|}{ Body weight (g) } & $2029.20 \pm 1.28$ & $2031.20 \pm 6.19$ & $2032.20 \pm 5.43$ \\
\hline \multirow{2}{*}{$\begin{array}{c}\text { The relative } \\
\text { weight of testis\% }\end{array}$} & Right & $17.60^{\mathrm{b}} \pm 0.50$ & $23.80^{a} \pm 0.73$ & $25.40^{\mathrm{a}} \pm 0.50$ \\
\hline & Left & $19.20^{\mathrm{b}} \pm 0.37$ & $25.00^{\mathrm{a}} \pm 0.31$ & $26.20^{\mathrm{a}} \pm 0.42$ \\
\hline \multirow{2}{*}{$\begin{array}{l}\text { Length of the } \\
\text { testis }(\mathrm{cm})\end{array}$} & Right & $4.75^{\mathrm{c}} \pm 0.05$ & $4.90^{\mathrm{b}} \pm 0.04$ & $5.36^{\mathrm{a}} \pm 0.02$ \\
\hline & Left & $5.06^{c} \pm 0.03$ & $5.77^{b} \pm 0.07$ & $6.05^{\mathrm{a}} \pm 0.04$ \\
\hline \multirow{2}{*}{$\begin{array}{l}\text { Width of the } \\
\text { testis }(\mathrm{cm})\end{array}$} & Right & $2.20^{\mathrm{c}} \pm 0.02$ & $2.62^{b} \pm 0.09$ & $2.86^{\mathrm{a}} \pm 0.03$ \\
\hline & Left & $2.24^{\mathrm{c}} \pm 0.02$ & $2.62^{b} \pm 0.08$ & $2.86^{\mathrm{a}} \pm 0.02$ \\
\hline \multirow{2}{*}{$\begin{array}{l}\text { The volume of } \\
\text { testis }\left(\mathrm{cm}^{3}\right)\end{array}$} & Right & $7.51^{\mathrm{c}} \pm 0.21$ & $11.28^{\mathrm{b}} \pm 0.85$ & $14.62^{\mathrm{a}} \pm 0.37$ \\
\hline & Left & $8.04^{c} \pm 0.25$ & $12.75^{\mathrm{b}} \pm 0.49$ & $16.49^{a} \pm 0.19$ \\
\hline
\end{tabular}

T1: Control treatment, T2, T3: 400 and 800mg of alcoholic extract of $E$. sativa seed : Different superscript in a row indicates a significant difference at $\mathbf{P}<0.05$.

Table (3) exhibited significant differences in the diameter of seminiferous tubules and in the thickness of the seminiferous testes epithelium $(\mathrm{P}<0.05)$ among treatments. A significant increase was found in the second and third treatments $(\mathrm{P}<0.05)$ compared to control. Such findings were compatible with Salem \& Moustafa (2001) who clarified that E. sativa seed oil increased the diameter of the seminiferous tubules. These increase in the diameter of seminiferous tubules and thickness of the seminiferous epithelium may be due to the watercress seed contain antioxidants, vitamins E, C, carotene, selenium and flavonoids (Alam et al, 2007). Antioxidant functions of watercress have been revealed by the existence of vitamin $\mathrm{C}$ in it (Nouri et al., 2008). The existence of these components in the alcoholic extract of garden rocket seed may have influenced the partial enhancement of sperm indexes. Vitamin E improved the histological properties of the testicle and increases the thickness of the seminiferous epithelium (Mather et al, 1983; Al-Salhie et al, 2017). On the other hand, there was a significant correlation between the weight of the testes and the diameter of seminiferous tubules and the thickness of the 
seminiferous epithelium (Wilson et al., 1988). Also, there was a significant correlation between the relative weight of testes and Spermatogonia (Yarney \& Sanford, 1993). As well as, there is indeed a strong correlation between tubular diameter and seminal activity
(Wilson et al., 1988). Hoseini et al, (2009) proposed that the presence of flavonoids and some other antioxidants in the alcoholic extract of E. sativa seed could enhance sperm indexes close to optimal.

Table (3): Effect of alcoholic extract of $E$. sativa seed on the histological characters of testes for aged local duck males (Mean $\pm \mathrm{SE}$ ).

\begin{tabular}{|c|c|c|}
\hline Treatments & $\begin{array}{c}\text { The thickness of the seminiferous } \\
\text { epithelium }(\mu \mathrm{m})\end{array}$ & $\begin{array}{c}\text { The diameter of seminiferous } \\
\text { tubules }(\mu \mathrm{m})\end{array}$ \\
\hline T1 & $106.20^{\mathrm{c}} \pm 2.74$ & $227.20^{\mathrm{c}} \pm 2.39$ \\
\hline T2 & $118.80^{\mathrm{b}} \pm 0.86$ & $245.00^{\mathrm{b}} \pm 1.92$ \\
\hline T3 & $129.60^{\mathrm{a}} \pm 1.74$ & $254.20^{\mathrm{a}} \pm 1.46$ \\
\hline
\end{tabular}

T1: Control treatment, T2, T3: 400 and $800 \mathrm{mg}$ of alcoholic extract of $E$. sativa seed : Different superscript in a column indicates a significant difference at $P<0.05$.

The Luteinizing hormone (LH), Folliclestimulating hormone (FSH) and Testosterone hormone concentration levels presented in table (4). The data in this table revealed significant $\quad(\mathrm{P}<0.05) \quad$ differences among treatments. A clear and significant $(\mathrm{P}<0.05)$ improvement of serum hormone concentration levels recorded in the second and third treatments compared to the first treatment. The findings presented in table (4) declared that the highest significant $(\mathrm{P}<0.05)$ hormone concentration level was recorded at the third treatment compared to other treatments. This result was agreed with Mohammadi et al, (2017) who reported a dose of $500 \mathrm{mg} \cdot \mathrm{kg}^{-1}$ watercress extract could significantly improve the level of LH, FSH and testosterone compared to the control. These increases in the level of hormone concentrations may be due to the feed supplementation of watercress extract which enhanced the body-ducks' hormone balance. It is therefore feasible that the extract of watercress is efficient on hormones connected with sperm indexes. The data obtained are consistent with those mentioned by Hussein (2013) who noticed an increase in testosterone levels in albino mice administered daily with 30 and 40 mg. $\mathrm{kg}^{-1}$ body weight of $E$. sativa leaves aqueous extract for thirty-five days.

Chemical and physical tests of the breast meat were showed in table (5). The results had no significant among all treatments in the ratio of free fatty acids, $\mathrm{pH}$ and water tolerability. The results indicated, the second treatment was recorded a lowest value for the number of peroxide compared to other treatments. While, the first treatment was recorded a highest value compared to others. 
Al-Salhie \& Makki / Basrah J. Agric. Sci., 33 (1): 221-230, 2020

Table (4): Effect of alcoholic extract of $E$. sativa seed on some hormones concentration for aged local duck males (Mean $\pm \mathrm{SE})$.

\begin{tabular}{|c|c|c|c|}
\hline Treatments & $\begin{array}{c}\text { Luteinizing } \\
\text { hormone(LH) IU . } \mathrm{L}^{-1}\end{array}$ & $\begin{array}{c}\text { Follicle-stimulating } \\
\text { hormone (FSH) IU.L }\end{array}$ & $\begin{array}{c}\text { Testosterone hormone } \\
\left(\mathrm{ng} . \mathrm{ml}^{-1}\right)\end{array}$ \\
\hline T1 & $0.87^{\mathrm{b}} \pm 0.05$ & $1.48^{\mathrm{b}} \pm 0.10$ & $1.41^{\mathrm{b}} \pm 0.21$ \\
\hline T2 & $1.28^{\mathrm{a}} \pm 0.08$ & $1.81^{\mathrm{a}} \pm 0.12$ & $2.01^{\mathrm{a}} \pm 0.02$ \\
\hline T3 & $1.44^{\mathrm{a}} \pm 0.16$ & $1.92^{\mathrm{a}} \pm 0.02$ & $2.15^{\mathrm{a}} \pm 0.02$ \\
\hline
\end{tabular}

T1: Control treatment, T2, T3: 400 and 800mg of alcoholic extract of Eruca sativa seed: Different superscript in a column indicates a significant difference at $\mathbf{P}<0.05$.

Table (5): Effect of alcoholic extract of $E$. sativa seed on fatty Acid ratio, peroxide, $\mathrm{pH}$ and water tolerability in meat of local duck males (Mean $\pm \mathrm{SE})$.

\begin{tabular}{|c|c|c|c|c|}
\hline Treatments & Fatty acids \% & $\begin{array}{c}\text { Number of } \\
\text { peroxides }\end{array}$ & $\mathrm{pH}$ & $\begin{array}{c}\text { Water } \\
\text { Tolerability\% }\end{array}$ \\
\hline $\mathrm{T} 1$ & $0.94 \pm 0.01$ & $0.94^{\mathrm{a}} \pm 0.02$ & $6.35 \pm 0.27$ & $63.76 \pm 0.61$ \\
\hline $\mathrm{T} 2$ & $0.78 \pm 0.04$ & $0.71^{\mathrm{b}} \pm 0.01$ & $6.39 \pm 0.43$ & $68.95 \pm 2.85$ \\
\hline $\mathrm{T} 3$ & $0.88 \pm 0.08$ & $0.78^{\mathrm{ab}} \pm 0.07$ & $6.38 \pm 0.11$ & $67.15 \pm 2.05$ \\
\hline
\end{tabular}

T1: Control treatment, T2, T3: 400 and $800 \mathrm{mg}$ of alcoholic extract of $E$. sativa seed*: Different superscript in a column indicates a significant difference at $\mathbf{P}<0.05$.

\section{Conclusion}

It can conclude from present study that alcoholic extract of E. sativa seed may improve reproductive parameters and sex hormones in males of aged local ducks. This can also influence positively on the number of peroxides in breast meat.

\section{Acknowledgements}

The author is very much grateful to College of Agriculture at University of Basrah for the support of this study.

\section{Conflict to interest}

There is no conflict of interest.

\section{Ethical approval}

All applicable institutional, national and international guidelines for the care and use of animals were followed.

\section{References}

Alam, M.S.; Kaur, G.; Jabbar, Z.; Javed, K. \& Athar, M. (2007). Eruca sativa seeds possess antioxidant activity and exert a protective effect on mercuric chloride induced renal toxicity. Food Chem. Toxicol., 45(6): 910920.

https://doi.org/10.1016/j.fct.2006.11.013

Amin, A. \& Hamza, A.A. (2006). Effects of roselle and ginger on cisplatin-induced 


\section{Al-Salhie \& Makki / Basrah J. Agric. Sci., 33 (1): 221-230, 2020}

reproductive toxicity in rats. Asian J.

Androl.,

8:

607-612.

https://doi.org/10.1111/j.1745-

7262.2006.00179.x

Al-Salhie, K.C.K \& Al- Waeli, A.M. (2019).

The effect of using different levels of red ginseng roots powder on some physiological characteristics of Japanese Quail males (Coturnix japonica). Basrah J. Agric. Sci., 32(1):

34-38.

https://doi.org/10.37077/25200860.2019.124

Al-Salhie, K.C.K. (2018). The effect of age on growth and development of the gonads preto post sexual maturity of Japanese quail (Coturnix japonica). Kufa J. Agric. Sci., 10(3): 39-55.

Al-Salhie, K.C.K.; Al-Hummod, S.K.M. \& Abbas, R.J. (2017). Effect of supplementation different levels of vitamin $\mathrm{E}$ and pumpkin seed oil to the diet on productive, physiological and reproductive performance of Japanese quail. Basrah $\mathrm{J}$. Agric. $\quad$ Sci., 30(2): 50-58. https://doi.org/10.37077/25200860.2017.44

AOAC: Association of Official Analytical Chemists (2016). Official Method Analysis, 20th Ed., Washington: 2: 3172pp.

Ballester, J.; Munoz, M.C.; Dominguez, J.; Rigau,T.; Guinovart, J.J. \& Rodriguez-Gil, J.E. (2004). Insulin dependent diabetes affects testicular function by $\mathrm{FSH}$-and $\mathrm{LH}$ linked mechanisms. J Androl., 25: 706-719. https://doi.org/10.1002/j.19394640.2004.tb02845.x

Chung, F.L.; Morse, M.A.; Eklind, K.I. \& Lewis, J. (1992). Quantitation of human uptake of the anticarcinogen phenethyl isothiocyanate after a watercress meal.
Cancer Epidemiol. Biomarkers Prev., 1: 383-388.

Davies, S.; Cros, T.; Richard, D.; Meddle, S.L.; Tsutsui, K. \& Deviche, P. (2015). Food availability, energetic constraints and reproductive development in a wild seasonally breeding songbird. Funct. Ecol.; 29(11): 1421-1434. https://doi.org/10.1111/1365-2435.12448.

Eady, M.; Samuel, D. \& Bowker, B. (2014). Effect of $\mathrm{pH}$ and postmortem aging on protein extraction from broiler breast muscle. Poult. Sci., 93(7): 1825-1833. https://doi.org/10.3382/ps.2013-03619.

Garg, G. \& Sharma, V. (2014). Eruca sativa (L.): Botanical Description, Crop Improvement, and Medicinal Properties. Journal of Herbs, Spices \& Medici. Plants, 20(2):171-182.

https://doi.org/10.1080/10496475.2013.8482 54

Getahun, S.M. \& Chung, F.L. (1999) Conversion of glucosinolates to isothiocyanates in humans after ingestion of cooked watercress. Cancer Epidemiol. Biomarkers Prev., 8(5): 447-451.

Helana, N.M.; Reham, E.S. \& George, E.R. (2011) Studies on the chemical constituents of fresh leaf of Eruca sativa extract and its biological activity as anticancer agent in vitro. J Med. Plant Res., 5: 1184-1191.

Hoseini, H.F.; Ahmad, G.R.; Saeidnia, S.; Naghi, S.M. \& Hadjiakhoondi, A. (2009). The effect of Nasturtium officinale on blood glucose level in diabetic rats. Pharmacology, 3: 866-871. 


\section{Al-Salhie \& Makki / Basrah J. Agric. Sci., 33 (1): 221-230, 2020}

Hussein, Z.F. (2013). Study the effect of Eruca sativa leaves extract on male fertility in albino mice. J. Al-Nahrain Univ., 16(1): 143-146.

Kim, S.J.; Jin, S. \& Ishii, G. (2004). Isolation and structura elucidation of $4-\beta-D$ glucopyranosyl disulfanyl butyl glucosinolate from leaves of rochet salad (Eruca sativa L.) and its antioxidative activity. Biosci. Biotechnol. Biochem., 68(12): 2444- 2450. https://doi.org/10.1271/bbb.68.2444

Mather, J.P.; Seaz, M.J.; Dray, F.\& Haour, F. (1983). Vitamin E prolongs survival and function of porcine Leydig cells in culture. Acta Endocrinol., 102: 470-475. https://doi.org/10.1530/acta.0.1020470.

Manach, C.; Morand, C.; Crespy, V.; Demigne, C.; Texier, O.; Regerat, F. \& Rémésy, C. (1998). Quercetin is recovered in human plasma as conjugated derivatives which retain antioxidant properties. FEBS Lett., 426: 331-336. https://doi.org/10.1016/s00145793(98)00367-6

Merza, H.; Homady, H.H. ; Hussain, K.A.; Tarawneh, J.M.; Shakhanbeh, I.A.A. \& Brain, P.F. (2000). Effects of oral application of some medicinal plants extract used in Jordan on social aggression as well as testicular and preputial gland structures in male mice. Pak. Biol. Sci., 3(3): 398-402. https://doi.org/10.3923/pjbs.2000.398.402

Mohammadi, J.; Motlagh, F.T. \& Mohammadi, N. (2017). The effect of hydroalcoholic extract of watercress on parameters of reproductive and sex hormones on the diabetic rats. J. Pharm. Sci. Res., 9(8): 13341338.
Nail, T.N.A.; Ali, M.M. \& Salim, E.A. (2017). Phytochemical studies on Sudanese Rocket (Eruca sativa) seeds and oil constituents. Am. J. Phytomed. Clin. Ther., 5(1): 1-5.

Nouri, M.; Ghasemzadeh, A.; Farzadi, L.; Shahnazi, V. \& Ghaffari, N.M. (2008). Vitamins C, E and lipid peroxidation levels in sperm and seminal plasma of asthenoteratozoospermic and normozoospermicmen. Iran. J. Reprod. Med., 6(1): 1-5.

N.R.C. (1994). National Research Council. Nutrient Requirements of Poultry. $9^{\text {th }}$ edn. Nat. Acad. Sci.. Washington, D.C.:176pp.

Okpe, G.C. \& Udoumoh, A.F. (2016). Effect of season on structural composition of drake testes and daily spermatozoa production as determined by quantitative testicular histology. Med. Weter, 72(10): 627-631.

Peegel, H.; Towns, R.; Nair, A. \& Menon, K.M. (2005). A novel mechanism for the modulation of luteinizing hormone receptor mRNA expression in the rat ovary. Mol. Cell Endocrinol., 233: 65-72. https://doi.org/10.1016/j.mce.2004.12.009

Salem, M.A.R. \& Moustafa, N.A. (2001). Histological and quantitative study of the effect of Eruca sativa seed oil on the testis of albino rat. Egyptian J. Hosp. Med., 2: 148-162.

Segatelli, T.M.; Franca, L.R.; Inheiro, F.P.; Alemida, C.C.D.; Martinez, M. \& Martinez, F.E. (2004). Spermatogenic cycle length and spermatogenic efficiency in the Gerbil (Meriones unguiculatus). J. Androl., 25: 872-880. https://doi.org/10.1002/j.19394640.2004.tb03156.x. 


\section{Al-Salhie \& Makki / Basrah J. Agric. Sci., 33 (1): 221-230, 2020}

Shahrokhi, N.; Khaksari. H.M.; Keshavarzi, Z. \& Shabani, M. (2009). Effects of aqueous extract of watercress on glucose and lipid plasma in streptozotocin induced diabetic rats. Pak J Physiol., 5(2): 6-10.

SPSS (2016). Statistical Packages of Social Sciences. IBM Corp. Released 2016. IBM SPSS Statistics for Windows, Version 24.0. Armonk, NY: IBM Corp. https:// www. ibm. com/ analytics/spss-statistics-software

Sultan, A.T.M.; Al-Salhie, K.C.K.\& Shawket,T.F. (2019).Effect of adding Lycium barbarum L. extract to drinking water on some productive traits of Japanese quail (Coturnix japonica) . Basrah J. Agric. Sci., $\quad 32(\quad 208-212$ 2 https://doi.org/10.37077/25200860.2019.210

Sultan, A.T.M.; Shawket, T.F. \& Al-Salhie, K.C.K.(2020). Effect of adding Lycium barbarum extract to drinking water on some physiological characteristics of Japanese quail (Coturnix japonica). AIP Conference Proceedings $2235 \quad$ (020031): 5pP. https://doi.org/10.1063/5.0007488
Vatsalya, V. \& Arora, K.L. (2012). Allometric growth of testes in relation to age, body weight and selected blood parameters in male Japanese quail (coturnix coturnix japonica). Int. J. Poult. Sci., 11(4): 251-258. https://doi.org/10.3923/ijps.2012.251.258

Wilson, J.L.; Kristo, M.; McDaniel, G.R. \& Sutton, C.D. (1988). Correlation of broiler breeder male and testes morphology. Poult. Sci. 67(4): 660-668. https://doi.org/10.3382/ps.0670660.

Yakubu, M.T.; Akanji, M.A. \& Oladiji, A.T. (2007). Male sexual dysfunction and methods used in assessing medicinal plants with aphrodisiac potentials. Phcog. Rev., 1(1): 49-56.

Yarney, T.A. \& Sanford, L.M. (1993). Pubertal development of ram lamb: physical and endocrinological traits in combination as indices of post pubertal reproductive function. Theriogenology, 40(4): 735-744. https://doi.org/10.1016/0093-

691X(93)90209-N 
تأثير المستخلص الكحولي لبذور الجرجير(Eruca sativa (L.) في بعض الصفات التناسلية ونوعية ذبائح ذكور البط المحلي المسنة

خالا جلاب كريدي الصالحي وغيداء علي مكي

قسم الانتاج الحيو اني، كلية الزراعة، جامعة البصرة، العراق

Knnz1977@yahoo.com

المستخلص: هدفت الدراسة الحالية لمعرفة تأثير المؤشرات التناسلية ونو عبة ذبائح ذكور البط المحلي المسنة. أستخدم 45 ذكر أ محلياً

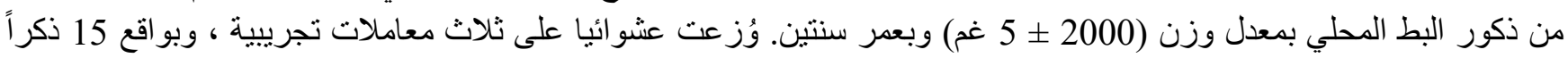

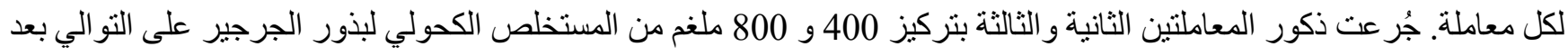

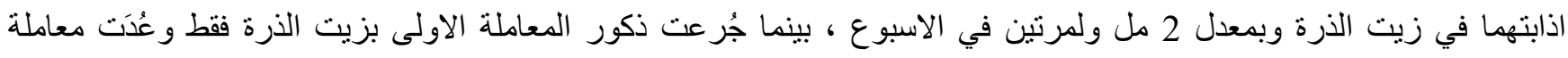

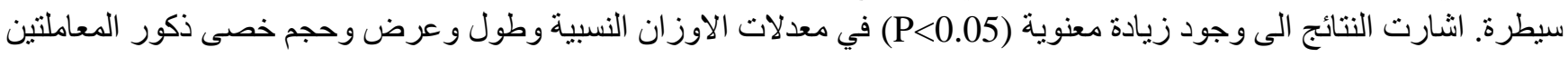

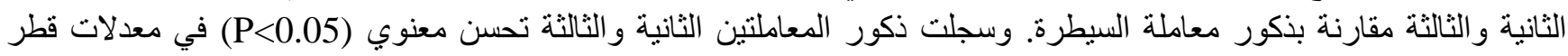

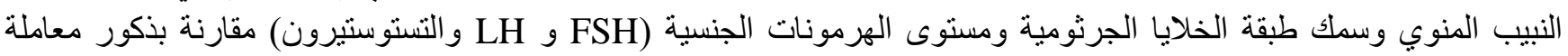

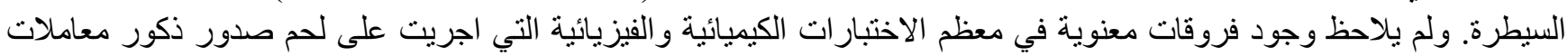

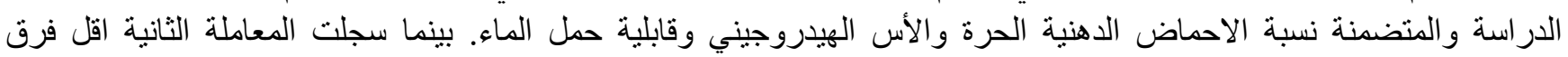

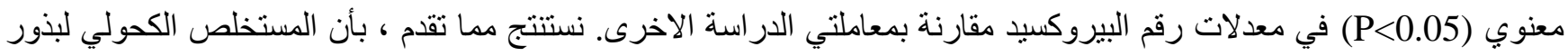

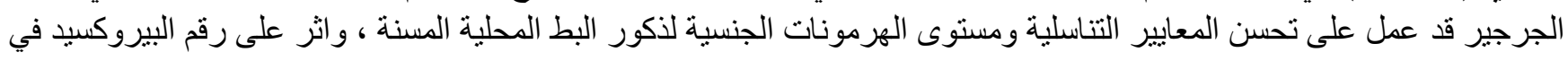
لحومها.

الكلمات المفتاحية: الجرجير، البط، الصفات التناسلية. 